\title{
Wound Healing Effect of Methanol Leaf Extract of Napoleona Vogelii Family (Lecythidaceae)
}

\author{
Enye J.C. ${ }^{1}$, Chineke, H.N. ${ }^{2}$, Onubeze D.P.M. ${ }^{3}$, Nweke I. ${ }^{4}$ \\ ${ }^{I}$ Department of Pharmacology and Toxicology Madonna University, Elele River State Nigeria \\ ${ }^{2}$ Department Of Family Medicine, Imo State University Teaching Hospital Orlu, South Eastern Nigeria. \\ ${ }^{3}$ Department of Community Medicine \& Primary Care, Anambra State University Teaching Hospital, Awka, \\ Nigeria \\ ${ }^{4}$ Department of Pharmacology, Abia State University Teaching Hospital, Aba, Nigeria
}

\begin{abstract}
Background: Wounds which results from an injury or trauma to any tissue of the body, has been claimed to be managed by traditional healers, with over fifty plants reported to have shown wound healing effect or properties.

A good example is the Napoleona Vagelii commonly called Mkpodu in Igbo language. Extract from this plant is sometimes prepared as polyherbal medicine. The use of plant extract in the external management of wound is becoming widely acceptable because there is a growing interest in the clinical practice of wound management with the use of chemical component impregnated dressing.
\end{abstract}

Objectives: To confirm the wound healing property of Napoleona Vagelii plant as claimed by folkloric medicine.

Methodology: A total number of 20 adult albino rats and 12 mice were used for the wound healing study and for the LD50 study respectively. They were provided with adequate food, drinking water and comfortable cage and housed at the Madonna University animal house. The rats were grouped into five groups of four rats in each group. The hairs of the trunk part of the rats were shaved with a razor and $1.5 \mathrm{~cm}$ wound was inflicted on each rat using a surgical blade. Petroleum jelly (Vaseline) was applied topically on the wounds of Group A rats, $2 \mathrm{mg}$ of Neobacin was applied topically on the wounds of group B rats, while 50mg, 100mg and 150mg of Napoleona Vagelii leaf extracts were also applied topically on the wounds of group $C, D$, and $E$ rats respectively. The various applications for each group of rats were done on alternate days and the diameter of the wounds measured to assess healing responses.

Results: It showed that the methanol extract of Napoleona Vogelii leaf has a wound healing activity, which was however not dose dependent. It showed a very significant wound healing $(P<0.5)$

Conclusion: Improvement in wound healing by the application of extract of Napoleona Vogelii leaf has been demonstrated by this research. Further works should be carried out by researchers to formulate a medicament for human use from it.

Key Words: Wound healing, effect, Napoleona Vogelii extract.

\section{Introduction}

Herbs were the predominantly used therapeutic agents from 2000BC to the $19^{\text {th }}$ century. ${ }^{(1)}$

This continued until the $19^{\text {th }}$ century when drugs isolated from natural sources became popular. Today more than ever before, people are seeking alternative opinions on how diseases should be treated and prevented. About $80 \%$ of the population in the developing world depends directly on traditional medicinal plants for primary health care. ${ }^{(2)}$

In our society, the predominance of synthetic drugs is being challenged by the use of herbs as alternative drugs, a trend which began around 1975. Herbs have become popular as an alternative to conventional drugs. ${ }^{(3)}$

Wounds, caused by an injury or trauma to any tissue of the body has been claimed to be managed by traditional healers with over fifty plants reported to possess wound healing properties. A typical example is the Napoleona vogelli whose leaf extract are sometimes prepared as polyherbal medicine, having shown to have curative effects for ailments like diarrhea and arthritis, aside its wound healing effect ${ }^{(4)}$.

A positive result or outcome of this study will be of immense benefit to the medical world as it will provide a cheap source of medicine for patients sustaining injury, since the plant is widely available and also cheap to obtain. 


\section{Materials And Methods}

Materials: Equipment, solvents, standard drugs, apparatus, chemicals and animal feed.

Equipment: Electric blender weighing balance, evaporator, refrigerator, water bath with vibrator, hot air oven, vacuum pump, mortar and pestles.

Solvents: Distilled water Vaseline (Petroleum jelly) methanol.

Standard drug: Gicatrin powder (Neobacin)

Apparatus: Funnel, conical flask, Beaker, measuring cylinder, cotton wool, latex hand gloves, permanent marker, Handkerchief, syringes, test tubes, forceps, spatula, whatman filter paper.

\subsection{Methodology}

\section{Plant collection and taxonomy}

Some quantities of the leaves of Napoleona vogelii were bought from Owerri market in October 2010. They botanical identification of the plant was done by a certified botanist. The leaves were later dried at room temperature and crushed to powder form by an electric blender.

Extraction: $150 \mathrm{~g}$ of the powdered leaf was extracted with 1.5 litres of methanol in a cold maceration process for 48hours. The crude methanol extract was concentrated using a rotary evaporator. Before the concentration process, the mixture was allowed to settle, it was decanted and the supernatant was filtered initially with a white handkerchief and then with a filter paper, the supernatant gave $340 \mathrm{ml}$. The evaporator was kept at a temperature of $40^{\circ} \mathrm{C} .1 \mathrm{ml}$ of the extract was taken and dried to get the extracted value of $0.22 \mathrm{mg}$.

\section{Phytochemical screening}

Qualitative assay for the presence or absence of secondary plant metabolites such as alkaloids, glucosides, terpenoids, carbohydrates, flavonoids, tannins, saponins etc were done on the methanol extract of the powdered leaf of Napoleona vogelii following a standard procedure (Evans 2010).

\section{Experimental Animals}

Twenty five adult albino rats and twelve mice were obtained from the University of Nigeria Nsukka. The animals were housed in wired cages arranged in rows and kept in the animal house of the department of pharmacology and toxicology of Madonna University Elele. The animal house was kept clean and the animals were fed with standard growers marsh and water. They were maintained in this condition throughout the period of the experiment.

\section{Acute toxicology test:}

This was carried out to determine the safety of the extract on the animals. The method of LD50 employed was Lorkes method 1983. The test was carried out in two stages.

Stage I: 3 groups of mice in each group.

Stage 1: Received $10 \mathrm{mg} / \mathrm{kg}$.

Stage 2: Received $100 \mathrm{mg} / \mathrm{kg}$.

Stage 3: Received $1000 \mathrm{mg} / \mathrm{kg}$.

The animals were monitored constantly for 24hours and the number of deaths was noted if any, after which the results obtained were used for the second stage.

Stage II: A total of three mice were used, one per group.

Group 1: Received $1500 \mathrm{mg} / \mathrm{kg}$ of the extract.

Group 2: Received 3000mg/kg.

Group 3: Received $5000 \mathrm{mg} / \mathrm{kg}$.

The animals were closely monitored for 24hours.

\section{Wound healing study}

The rats were grouped into five groups of four rats each. The hairs of the trunk part of the rats were shaved with a razor and $1.5 \mathrm{~cm}$ wound was inflicted on each rat using a surgical blade. Petroleum jelly (Vaseline) was applied topically on the wounds of Group A rats; $2 \mathrm{mg}$ of cicatrin (Neobacin) was applied on the wounds of Group B rats; while 50mg, 100mg and 150mg of Napoleona Vogelii leaf extract were also applied on the wounds of group C, D and E rats respectively. The treatments were repeated every two days on each group and the diameter of the wounds measured to assess the healing response. 


\section{Statistical Analysis:}

Results were expressed as mean + standard errors. The significance of difference between control and treated groups were determined by one way analysis of variance (ANOVA). Results were regarded as significant with $(\mathrm{P}<0.05)$.

Percentage yield of the extract was:

\section{Results}

$=\underline{\text { Weight }}$ of Extract $\times 100$

Weight of Powdered material

$=\quad \frac{74.8}{150} \times 100=49.8 \%$

150

\section{Tables: Result Of Acute Toxicity.}

Table 1: Lethal dose for 10,100 and $1000 \mathrm{mg} / \mathrm{kg}$.

\begin{tabular}{|l|c|c|c|}
\hline \multicolumn{1}{|c|}{ Dose } & No of mice & $\begin{array}{c}\text { Number of } \\
\text { death }\end{array}$ & $\begin{array}{c}\text { Number of } \\
\text { survival }\end{array}$ \\
\hline $10 \mathrm{mg} / \mathrm{kg}$ & 3 & 0 & 3 \\
\hline $100 \mathrm{mg} / \mathrm{kg}$ & 3 & 0 & 3 \\
\hline $1000 \mathrm{mg} / \mathrm{kg}$ & 3 & 0 & 3 \\
\hline
\end{tabular}

Table 2: Lethal dose for $1500,3000,5000 \mathrm{mg} / \mathrm{kg}$.

\begin{tabular}{|l|c|c|c|}
\hline Dose & $\begin{array}{c}\text { Number of } \\
\text { mice }\end{array}$ & $\begin{array}{c}\text { Number of } \\
\text { death }\end{array}$ & $\begin{array}{c}\text { Number of } \\
\text { survival }\end{array}$ \\
\hline $1500 \mathrm{mg} / \mathrm{kg}$ & 1 & 0 & 1 \\
\hline $3000 \mathrm{mg} / \mathrm{kg}$ & 1 & 0 & 1 \\
\hline $5000 \mathrm{mg} / \mathrm{kg}$ & 1 & 0 & 1 \\
\hline
\end{tabular}

Table 3: Wound healing study.

\begin{tabular}{|l|c|l|l|l|l|}
\hline Group & \multicolumn{1}{|l|}{ Med } & $\begin{array}{l}\text { Initial wound } \\
(\mathbf{c m})\end{array}$ & $\mathbf{T}_{\mathbf{1}}$ & $\mathbf{T}_{\mathbf{2}}$ & $\mathbf{T}_{\mathbf{3}}$ \\
\hline $\mathrm{A}$ & Vaseline & 1.5 & $1.25 \pm 0.05$ & $0.87 \pm 0.09$ & $0.75 \pm 0.19$ \\
\hline B & Neob. 2mg & 1.5 & $1.20 \pm 0.24$ & $0.35 \pm 0.05$ & $0.01 \pm 0.009$ \\
\hline C & 50mg Ext. & 1.5 & $0.85 \pm 0.05$ & $0.35 \pm 0.19$ & $0.13 \pm 0.07$ \\
\hline D & 100mg Ext. & 1.5 & $1.00 \pm 0.24$ & $0.65 \pm 0.19$ & $0.35 \pm 0.5$ \\
\hline E & $150 \mathrm{mg}$. & 1.5 & $0.87 \pm 0.09$ & $0.45 \pm 0.05$ & $0.35 \pm 0.05$ \\
\hline
\end{tabular}

Key:

Med $=$ Medication

Ext $=$ Extract

$\mathrm{T}_{1}=$ First treatment

$\mathrm{T}_{2}=$ Second treatment

$\mathrm{T}_{3}=$ Third treatment.

The remaining five rats were used as controls, one for each group. Similar wounds were inflicted on them, and left untreated. The wounds became septic, necrotic and increased tremendously in size in all the five animals.

\section{Discussion}

Plants containing gum and other related compounds have the tendency of healing wounds by acting as a protective agent covering and preventing microbial infections. ${ }^{(6)}$ The cellulose fibrils are arranged in a multidimensional net in the primary wall and the middle lamella containing a plastic cementing layer that holds the adjacent layers and reinforce one another. This deposition pattern seals the wound cells. ${ }^{(7),(8),(9)}$

The use of plant extract in the external management of wound is becoming widely acceptable because there is a growing interest in the clinical practice of wound management with the use of chemical componentimpregnated dressing. ${ }^{(10)}$

The result of the experiment showed that the methanol extract of Napoleona Vogelii leaves has a wound healing activity, although this was not dose dependent. It showed a very significant wound healing action with a P-value of less than 0.05 . However, comparing the action produced by the plant extract with that produced by the standard drug Neobacin (Cicatrin) used, $50 \mathrm{mg}, 100 \mathrm{mg}$, and $150 \mathrm{mg}$ of the extract produced a comparative effect with the Cicatrin powder although the standard drug Neobacin (Giatrin) seems to be more potent than the extract. 
The result of the acute toxicity test (LD50) carried out showed that the plant has a very high safety margin even when administered to a very high dose of $5000 \mathrm{mg} / \mathrm{kg}$.

The phytochemical analysis Of the leaf extract revealed the presence of glycosides, alkaliods, saponins, terpeniods, steroids, flavonoids, resins, proteins and carbohydrates. The wound healing effect of Napoleona Vogelii leaf extract could be due to the presence of some of these phytochemicals notably tannins, alkaloids glycosides and saponins. ${ }^{(8)}$ wounds.

This result of this experiment supports the folkloric use of Napoleona Vogelii for the treatment of

Napoleona vogelii is an evergreen and widely distributed plant with alternate leaves, usually crowded towards the apex of the branches. About 20 genera and 450 species have been identified in the tropical regions of Africa, Asia and Australia.

Its common names are Akpako, Boribori, Burukwa and its region of distribution is mostly in African countries of Nigeria, Ghana, Guinea, Togo, Benin, and Ivory coast. The leaves are glossy looking.

\section{Conclusion And Recommendation}

Napoleona vogelii has wound healing activity. Thus its role in folkloric medicine as a wound healing agent appears justified and worthy of further research. This will lead to the production of cheap drugs locally, and as a result capital flight which the country is experiencing currently as a result of huge importation of drugs from overseas can be abated.

\section{Reference}

[1]. Rajadurai M; Vidhya V. Ramya M., Annusha B. Ethnomedicinal Plants used by traditional healers. 2009; 3:39-41.

[2]. Gary Null. Complete Encyclopaedia of Natural Healing 1998; 5:220-222.

[3]. Iwu Maurine M. Handbook of African Medicinal Plants, CKC press 1993; 2:3-4

[4]. Valiathan M.S. Healing Plants. Current Science 1998; 75:1122-1126.

[5]. Evans W.C. Treas and Evans Pharmacology $15^{\text {th }}$ Edition 2001; 26:328-330.

[6]. Rate S.M. Plants as source of Drugs. Toxican 2001; 39:603-613.

[7]. Ibadan P.P. Complete Encyclopaedia of National Healing. 1999; 5:220-222.

[8]. Doughty O.B. Wound care strategies by the Homeopath Nurse 2004; 22(6) 364-366.

[9]. Bhora F.Y. Donkin B.J. Sidaway A.N. Effect of Growth Factors and epitheliaziation in Human skin. Journal of Surgical Research 1995; 59:236-244.

[10]. Fish F. Dawson J.I. Surgical Dressing, Ligatures and sutures. Heinemann Medical London 1969; 12:62-64. 